\title{
Teachers' Beliefs and Understandings of Their Roles in Micro Course Planning and Syllabus Design
}

\author{
Fitri Aprianti \\ Universitas Pendidikan Indonesia, Bandung, Indonesia \\ aprianti22.fitri@gmail.com
}

\begin{abstract}
Developing syllabus in language education program is critical, however, little is known on the actual roles that teachers play in it. Therefore, this study was intended to explore the EFL teachers' beliefs and understandings regarding their roles in micro course planning and syllabus design and how these aspects were realized in their context of teaching. This study employed qualitative approach with a descriptive study design. The respondents involved were three EFL teachers from a private English course. The data were collected by using interviews and documentations. Nunan's (2000) theory on the role of teachers in syllabus planning was used as the basis theory to analyse the data gathered. The result showed that the respondents mainly belief that their role in micro syllabus planning rely on two categories, these were as an implementer and as a decision maker. It was found that teachers tended to only have a greater freedom in deciding the revision, sequencing and grading of the course content while the other two stages which were stipulating goal and language level were determined by the institution.
\end{abstract}

Keywords: beliefs, understandings, roles, course planning and syllabus design

\section{INTRODUCTION}

Syllabus design is one of the integral processes of any language education program. It is stated that only a wellstructured and well-organized syllabus that can intensively act as a vehicle in establishing a well-developed language education program (Richards, 2002, pg. 145-147). Yet, it is stated that an ideal syllabus is the syllabus that suits its intended users, specifically teachers. Unless, teachers are familiar with the rationale of the syllabus design and/or planning, then the syllabus itself would be useless. Thus, the questions that highlight teachers' roles and positions in course planning and syllabus design remain persist. Research shows that depending on the context of the teaching course makes the teachers' role in syllabus planning may vary drastically (Tabari, 2013). This phenomenon has created confusion since the extent to which teachers could be involved in syllabus planning has not yet been clear.

Numbers of literatures have shown that there are various conceptions regarding the roles of teachers in course planning and syllabus design. Baldauf (2005), for example, claims that teachers' role is limited only on the implementation of the syllabus. This is supported by Kaplan \& Baldauf (2003) as they add that syllabus should be exclusively developed and planned only by applied linguists and/or government agencies. However, their statements have been criticized as their definition seems to refer only to macro or national scale syllabuses. Conversely, Nunan (2000) claims that in today's teaching and learning conditions and contexts, teachers may have a relatively free hand to get involved in designing their own syllabuses. In addition, Richards (2002) and Johnson (2009) state that the concept of syllabus planning can be different both in macro and micro level, thus, teachers may have a wider role in it.

Several research studies have also been conducted in order to investigate this issue ( $\mathrm{Li}, 2010$ and Rahimpuor, 2010). Li's (2010) findings indicate that there is a gap between content of course or syllabus divined by curriculum policy with the practical teaching situation. It means that there is a mismatch between the governments' perceive role of teachers in syllabus planning; that is as implementer, and teachers' perceive of their own role; that is as a planner. As the result, $\mathrm{Li}$ (2010) finds that teachers tend to drastically change the content to suit their condition. Therefore, he suggests that classroom teachers should be involved in syllabus planning so that the can be more applicable. Conversely, Rahimpour (2010) finds that even when teachers act as implementers they still could contribute to the improvement of the language education program.

Yet, again, although these studies have exemplified a significant number of teachers' perceive role and position in syllabus planning in a macro context, but it seems that these studies still have left one major gap. That gap is in a form of insufficient of information on how EFL teachers perceive their role in course planning in a micro setting especially in private English course in Indonesian context. As the result, there are two questions that assist this study to investigate that matter, the questions are formulated as follow: What beliefs and understandings do teachers have about their role in course planning and syllabus design? And How do teachers' perceive roles impact the cycle of the micro course planning and syllabus design?

\subsection{Beliefs and Understandings}

\section{LITERATURE REVIEW}

Beliefs and understandings are widely known as one of the major topics of interest in educational research (Malik \& Hamied, 2016 and Crookes, 2009 pg. 1-3). Investigating belief and understanding of an individual or a group of people on certain phenomenon may shed a light on how actions are taken and perceived to be appropriate for certain circumstance. Borg (2006) and Crookes (2009) also add that 'belief' can be held both consciously and/or subconsciously by individuals. Thus, it can be assumed that what teachers do and perceive are always governed by their thoughts, either consciously or subconsciously, and that their thoughts are determined by their beliefs and understandings (Freeman, 1996 pg. 560). Teachers' beliefs and understandings regarding their role in course planning and syllabus design, for example, 
may not always present in their thinking, but they underlie the actions that teachers make (ibid).

\subsection{Course Planning and Syllabus Design}

Course planning refers to a systemic approaches or ways of organizing a syllabus. In addition, syllabus is defined as the specification and ordering of content of a course (Nunan, 2000 and Richards, 2002, pg. 152-154). Course planning and syllabus design are part of the curriculum design as a whole (Graves, 2000). Developing a course and material design require careful planning and preparation. Richards (2002), for example, proposed that there are at least six dimensions of course development that should be carefully developed. These dimensions involve; developing course rationale, describing the entry and exit level of the target students, determining the scope and sequence of the course content as well as planning the course structure. Planning the course structure involves sequencing and grading the course content based on the selected syllabus design. Planning the source structure is what Richards (2002, pg. 152-153), Nunan (2000) and Brown (1995) claim as the most problematic stage in syllabus planning. There is a tendency that different practitioners may have different preference on syllabus design ( $\mathrm{Li}, 2010)$. Teachers have to decide the types of content to include or exclude or whether to combine various types of syllabus content or to rely on a single type (Nunan, 2000).

\subsection{Teachers' Role in Course Planning and Syllabus Design}

There are various conceptions regarding the roles of teachers in course planning and syllabus design. The roles spread out ranging from solely implementer of a readymade syllabus to a complete designer of a planned syllabus.

Teachers as implementer: The first argument on teachers' role is from Baldauf (2005). Baldauf (2005) claims that teachers' role is on the implementation of the syllabus. Teachers' role should only as an implementer of readymade syllabus. He views that syllabus will be exclusively develop and planned only by applied linguists and/or government agencies. Kaplan \& Baldauf (2003) also further add that syllabus planning should be carried out by people with specific expertise otherwise the end product may not be applicable.

Teachers as designer: In contrast, Nunan (2000) and Graves (2001) argue that nowadays, depending on the context of situations that teachers are dealing with, teachers may have a relatively free hand in designing their own syllabus. Teachers can take a role as planner for as long as they are accompanied by appropriate training, so that they will be equipped with necessary skills and information to design their own syllabuses (Nunan, 200).

Teachers as negotiator: Johnson (2009) prefers to regard syllabus planning as an open and negotiable process. Graves (2001) adds that syllabus should be negotiated by teachers and their students on the basis of the needs analysis. Johnson (2009) states that what we need is to provide reasonable room for teachers to divine their role on syllabus planning, because teachers tend to do what they know and what they belief (Freeman, 1996). A teacher who is not familiar with and belief in situating the content on the formal aspects of a language will not be likely to apply that syllabus. It means that unless teachers know their roles and position in syllabus design are then teachers may not accurately describe the syllabus itself (Brown, 1995).

\section{RESEARCH METHODOLOGY}

\section{a. Design}

This research study was aimed to investigate dynamic context of syllabus design and teachers' perceive roles in it. Therefore, the data used in this study were gained from natural setting without manipulation of the subjects being studied. In order to cope with the responses from the respondents, this research applied a descriptive qualitative research design (Creswell, 2012). The study is conducted in limited scale, thus, the result of the study is not meant to be generalized, yet, it can be used as an insight to this issue (Ibid).

\section{b. $\quad$ Setting and Respondent}

The setting of the study was in an English private course. The course was known as having its own independent curriculum as well as English language syllabus which was claimed to suit the students' need. Three teachers were participated as respondents of the study. The respondents were selected based on their interest and willingness to participate. In addition, the respondents also had various teaching experiences ranging from five to seventeen years.

\section{c. Data Collection and Data Analysis}

This research employed two instruments; they were interviews and document analysis. Interviews sections were given in a form of open-ended format in order to provide flexibility that both the researcher and the respondents might need (Creswell, 2012). At this point, the respondents were asked to reflect on their beliefs and understandings regarding their role in course planning and syllabus design as well as how that role was articulated into actual action. Documentations were used to validate the data that were gained from interviews. The documents which were collected were in a form of course books, syllabuses and teachers' notes.

In the process of data analysis, the data that was gained from interviews were analyzed and coded based on the classification of teachers' role and syllabus planning that are proposed by Nunan (2000) and Richards (2002). In addition, document analysis was conducted under the coding procedures developed by Creswell (2012).

\section{FINDINGS AND DISCUSSIONS}

\section{a. Teachers' Beliefs and Understandings of Their Role in Course Planning}

The respondents acknowledged the importance of developing language syllabus in language education program. Yet, there was an indication that the process of course planning and syllabus design did not entirely depend on teachers. Teachers perceived their role is in a middle of 
continuum between complete designer and complete implementer. These findings will be illustrated as follow.

\section{a. Teacher as an Implementer}

Teachers perceived that to some extent they carried a role as syllabus implementer. It means that teachers belief that the decisions in course planning could not be all taken by the teacher themselves. This idea was represented in these following comments:

R1: "Well I was given a book as my guideline, perhaps what you may call as syllabus. So, I thought that my institution have decided things [list of content] to be thought. Yet, I belief that its' not entirely complete. I need to add something to it, or even completely remove, you know, the content that I don't think would be good to be given to the students."

These tendencies were also addressed by Nunan (2000), in which he states that the involvement of teachers in designing a course syllabus may finally be extended and even restricted by several interrelated factors. These factors involves; status quo of the syllabus and teachers' level of expertise. The respondents highlighted that in their context, the status quo of syllabus was an instrument that can be negotiated. It means that the language course planning and syllabus design involve decisions that should be taken ranging from the highest to the lower levels, which means from institution to classroom teachers.

Respondent 3 stated that he was given a series of mentoring before, then she could independently decide what to and what not to involve in her syllabus. This findings seemed to be in line with Graves's (2001) as he claims that the intricacy of course planning rely mainly on the fact that every stakeholder that takes part on the decision making has to be accompanied by necessary skills needed if the end result of the syllabus itself is to be successful. The respondents also added that typically the factors that could not be negotiated, or compulsory to be implemented, were the content that closely related with the philosophical vision of the course. These philosophical visions were informed at the stage of the recruitment of the teachers, thus teachers knew the consequences and they tend to adjust themselves with it.

\section{b. Teacher as a Decision Maker}

It was found that the respondents indicated their view that their involvement in syllabus decision making may also be significant to be considered. The respondents' role as decision maker was reflected in the following statement:
R2: "We are typically given a series of content. It is not completely ready yet. The course gives us a chance to make adjustment. Sometimes I change the content, sometimes I add to it. I need to do this because otherwise it may not suit the students' needs."

These statements clarified Nunan's (2000) as he claims that there is no language syllabus that can be completely independent. It means that in this context the respondents were encouraged to participate in the revision, implementation and evaluation of the syllabuses. The respondents played their role in providing data from their actual teaching situation and as the result use it as inputs to the syllabus revision.

Respondent 2 added that she knew the structure of the syllabus that she used. Unless she knew how it was structured and why it was made that way, then she would not feel confident to teach it. These findings were again in line with Nunan (2000) who places language syllabus as an instrument of negotiation and/or to be negotiated. It means that the teachers could not be completely separated from the process of planning and making language syllabus design. As the institution leave room for significant variation in the way teachers put syllabus design into practice on the classroom level, then, teachers can play their role as decision makers or planners.

\section{b. The Implication of Teachers' Perceive Role in the}

\section{Stages of Syllabus Planning}

The findings showed that there were three major impacts caused by the teachers' perceive role in syllabus planning. These impacts are:

a. Teachers' treated compulsory content defined by the course as the basis of syllabus design.

b. Teachers' considered that adjustment and enrichment can be given to the compulsory content if necessary. This phenomenon typically affected the overall syllabus design.

c. Grading and sequencing of the content will entirely depend on teachers by considering the students' needs on their context of teaching. This tendency had brought teachers to have different segmentation of grading and sequencing from one to another.

This phenomenon has also been predicted by Graves (2001). He states that there is always a shift of syllabus design from period to other period and even from one teacher to the other teachers. This tendency happens since obviously teachers do have difference interests, preferences, beliefs and values. To be more precise, the preceding findings will be depicted in the following illustration.

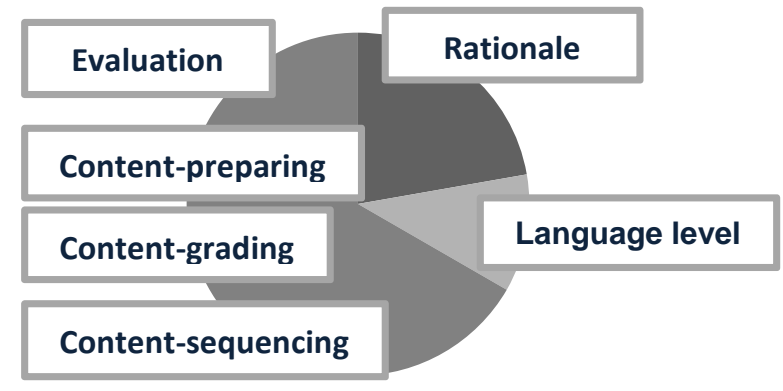

Content-selection 
The color gradation depicted in the diagram above illustrates gradual change of teachers' role in course planning and syllabus design. In this context, the first two stages, which were defining course rationale and students entry and exit language levels were completely dominated by the institution. It means that at these two stages, teachers perceived their role as implementer. As an implication, at this point, the respondents expected to be given base structure of the syllabus used by the institution in advance. The compulsory contents were usually given in a form of coursebook. R2: "I feel better if I get a general picture of the things that I should teach. But I need some, you know, a chance to enrich it. [pause] I think the list of language content that they give has not always been thoroughly complete though."

Handing out the coursebook by the institution to the teachers was signified as the transition phase of teachers' role from what was originally implementer to decision maker. Richards (2002) defines it as "Content Selection" stage. At this stage, the compulsory language content given in the institution was then reexamined. Teacher could directly adopt, adapt or make some compulsory change as needed. Therefore, at this point the level of changes may differ from teacher to teacher. Respondent 2 and 3 for example admitted that the recommendation of contents tend to be well made, therefore often times they only needed to make a light adjustment. Teachers 2 gave a slight different respond in which she stated that the proposal content given were too structural in nature, yet she found that her students often asked for a more communicative approach. Despite the difference degree of changes made in terms of content selection, yet, all of the teachers agree that they gain full responsibility of employing their role as decision maker in the last three stages of the course planning and syllabus design which were determining the final gradation, scope and sequence of the course. Teachers' decisions were taken based on the learners need and time allocation given by the course institution

\section{CONCLUSION}

This study takes micro level syllabus planning which is an English private course as the context of teaching. Here, it is found that teachers perceived the process of syllabus design as an instrument of negotiation. Their perceive roles as decision maker in course planning and syllabus design were articulated in the stage of adjusting the course content given by the institution. At this stage, teachers' will and the course intention were negotiated. The last two stage of course development, on the other hand, were entirely rely on teachers' decision based on the learners need and time allocation given by the course institution. Finally, for
EFL teachers it is expected that teachers should be fully aware of their role in course planning and syllabus design. By this case, it means that it is expected that teachers should carefully examine their context of teaching and carefully decide their role in course planning and syllabus design, accordingly, meaningful use of syllabus can be gained.

\section{REFERENCES}

Baldauf, J. R. B. (2005). Language planning and policy research: An overview. In E. Hinkel (ed.) Handbook of Research in Second Language Teaching and Learning. 1, pp. 957970.

Borg, S. (2006). Teacher cognition and language education. London: Continuum.

Brown, J. D. (1995). The Elements of Language Curriculum; A Systematic Approach to Program Development. Massachusetts: Heinle and Heinle Publishers.

Creswell, J. W. (2012). Educational Research; Planning, Conducting, and Evaluating Quantitative and Qualitative Research. USA: Pearson.

Crookes, G. (2009). Values, Philosophies, and beliefs in TESOL: Making a Statement. Cambridge: Cambridge University Press.

Freeman, R. D. (1996). Dual-language planning at Oyster Bilingual School: "It's much more than language”. TESOL Quarterly, 30 (3), pp. 557582.

Graves, K. (2000). Designing Language Courses. Canada: Heinle \& Heinle.

Graves. K. (2001). Teachers as Course Developers. USA: Cambridge University Press.

Johnson, D. C. (2009). The relationship between applied linguistic research and language policy for bilingual education. Applied Linguistics, 31 (1). pp. 72-93.

Kaplan, R. B., \& Baldauf, J. R. B. (2003). Language planning: From practice to theory. PA: Multilingual Matters.

Li, Mingli (2010). EFL teachers and English Language Education in the PRC: Are They the Policy Makers?. The Asia-Pacific Education Researcher Vol. 19 (3), pp. 439-451.

Nunan, David. (2000). Syllabus Design. Oxford: Oxford Press.

Malik, R. S. \& Hamied, F. A. (2016). Research Methods: A Guide for First Time Researchers. Bandung: UPI Press.

Rahimpour, M. (2010). Current Trends on Syllabus Design in EFL instruction. Procedia Social and Behavioral Sciences, 2. pp. 50-64.

Richards. J. C. (2002). Curriculum Development in Language Teaching. Cambridge: Cambridge University Press 
Tabari, A. G. (2013). Challenges of Language Syllabus Design in EFL/ESL Contexts. Journal of Language Teaching and Research. 4 (4), pp. 869-873. 